\title{
KAJIAN KESESUAIAN PEMILIHAN ANTIBIOTIK EMPIRIS PADA PASIEN ULKUS DIABETIKUM DI INSTALASI RAWAT INAP RUMAH SAKIT ABDUL WAHAB SJAHRANIE SAMARINDA
}

\author{
Melinda Rahmawati*, Vina Maulidya, Adam M. Ramadhan \\ Laboratorium Penelitian dan Pengembangan Kefarmasian "Farmaka Tropis", \\ Fakultas Farmasi, Universitas Mulawarman, Samarinda, Indonesia \\ *Email: melinda.rahmawati28@yahoo.com
}

\begin{abstract}
Diabetic ulcer is one of the cases that occurs due to complications from Type 2 Diabetes Mellitus which is characterized by the presence of open sores on the legs. To deal with these cases antibiotics are given to treat the infection. The selection of empirical antbiotics is an effort to determine the success rate of therapy for diabetic ulcers. This study aims to determine the characteristics, patterns of empirical antibiotic treatment, resistance patterns and bacterial sensitivity to antibiotics, and the accuracy of the selection of empirical antibiotics in diabetic ulcer patients. This study was an observational study with retrospective data collection and analyzed descriptively on the medical record of diabetic ulcer patients treated in the hospital of Abdul Wahab Sjahranie Samarinda in the period of January-December 2017. The inclusion criteria in this study were patients who had diagnosed aged diabetic ulcer adult. Based on research shows that the selection of empirical antibiotics that are often used is Ceftriaxone as a single therapy by $36 \%$ and Ceftriaxone-Metronidazole as a combination therapy by 50\%. The accuracy of antibiotic selection showed that ceftriaxone based on bacterial sensitivity test showed a percentage of suitability of $38.89 \%$ and Ceftriaxone + Metronidazole of $48 \%$.
\end{abstract}

Keywords: Diabetic ulcer, empirical antibiotics, resistance, sensitivity

\begin{abstract}
ABSTRAK
Ulkus diabetikum merupakan salah satu kasus yang terjadi akibat komplikasi dari Diabetes Mellitus Tipe 2 yang ditandai dengan adanya luka terbuka pada bagian kaki. Untuk menangani kasus tersebut dilakukan pemberian antibiotik untuk mengobati infeksi tersebut. Pemilihan antbiotik empiris merupakan salah satu upaya untuk mengetahui tingkat keberhasilan terapi pada ulkus diabetikum. Penelitian ini bertujuan untuk mengetahui karakteristik, pola pengobatan antibiotik empiris, pola resisten dan sensitivitas bakteri terhadap antibiotik, dan ketepatan dari pemilihan antibiotik empiris pada pasien ulkus diabetikum. Penelitian ini merupakan penelitian observasional dengan pengambilan data secara retrospektif dan dianalisis secara deskriptif pada catatan rekam medis pasien ulkus diabetikum yang dirawat di rawat inap RSUD Abdul Wahab Sjahranie Samarinda periode Januari-Desember 2017. Kriteria inklusi pada penelitian ini adalah pasien yang memiliki diagnosa ulkus diabetikum berusia dewasa (> 26 tahun). Berdasarkan penelitian
\end{abstract}


menunjukkan bahwa pemilihan antibiotik empiris yang sering digunakan adalah Seftriakson sebagai terapi tunggal sebesar $36 \%$ dan Seftriakson-Metronidazol sebagai terapi kombinasi sebesar 50\%. Ketepatan pemilihan antibiotik menunjukkan bahwa seftriakson berdasarkan uji sensitivitas bakteri menunjukkan persentase kesesuaian sebesar $38,89 \%$ dan Seftriakson+Metronidazol sebesar $48 \%$.

Kata kunci: Ulkus diabetikum, antibiotik empiris, resistensi, sensitivitas

DOI: $\underline{\text { https://doi.org/10.25026/mpc.v8i1.313 }}$

\section{PENDAHULUAN}

Ulkus diabetikum merupakan salah satu komplikasi dari Diabetes Mellitus yang ditandai dengan adanya luka terbuka pada bagian permukaan kulit yang disebabkan oleh adanya makroangiopati, sehingga terjadi vaskuler insufisiensi dan neuropati. Ulkus diabetikum dapat berkembang menjadi infeksi karena masuknya bakteri dan adanya gula darah yang tinggi menjadi tempat yang strategis untuk pertumbuhan bakteri $^{[21]}$. Indonesia menempati urutan keempat terbesar dengan jumlah penyandang DM di dunia setelah negara India, Cina, dan Amerika. Secara epidemiologi, diperkirakan pada tahun 2030 prevalensi penyandang DM di Indonesia mencapai 21,3 juta orang ${ }^{[17]}$.

Antibiotik merupakan zat biokimia yang diproduksi oleh mikroorganisme, yang dalam jumlah kecil dapat menghambat pertumbuhan atau membunuh pertumbuhan mikroorganisme lain ${ }^{[8]}$. Antibiotik yang dipilih harus memperhatikan beberapa hal, seperti: faktor spesifik pasien (usia, fungsi organ, tempat infeksi, dan derajat penyakit ulkus diabetikum), faktor organisme penyebab (peta kuman atau pola antibiotik, farmakokinetik, dan farmakodinamik, profil tolerabilitas dan keamanan, penetrasi ke jaringan dan azas, biaya dan manfaat). Terapi empiris merupakan pemberian awal terapi yang diberikan sebelum hasil kultur dan sensitivitas tes keluar. Tingginya terapi empiris dikarenakan uji kultur bakteri dan hasil kultur membutuhkan waktu empat sampai tujuh hari, sedangkan pengobatan harus segera dimulai tanpa menunggu hasil kultur. Sehingga diperlukan evaluasi terhadap penggunaan antibiotik empiris terhadap kultur bakteri. Pemilihan antibiotik empiris pada pasien ulkus diabetikum diharapkan memenuhi aspek ketepatan. Selain itu, dapat mengetahui jenis bakteri yang menjadi penyebab serta pola sensitivitas bakteri ${ }^{[12]}$.

\section{METODOLOGI PENELITIAN}

Penelitian ini dilakukan dengan menggunakan rancangan penelitian observasional, pengambilan data secara retrospektif menggunakan catatan rekam medis pasien. Teknik pengambilan sampel yang akan digunakan dalam penelitian ini adalah menggunakan teknik purposive sampling, yaitu suatu teknik pengambilan sampel yang dilakukan dengan cara memilih sampel dari populasi yang dilakukan secara tidak acak dan pengambilan sampel dipilih berdasarkan pertimbangan tertentu dari peneliti berdasarkan ciri atau sifat karakteristik populasi yang telah diketahui.

Populasi penelitian adalah semua pasien Diabetes Mellitus (DM) yang dirawat di RSUD Abdul Wahab Sjahranie Samarinda. Sampel yang digunakan adalah data rekam medis pasien DM dengan komplikasi Ulkus Diabetikum yang dirawat pada tahun 2017 yang 
memenuhi kriteria inklusi. Kriteria inklusi pada penelitian ini adalah pasien yang memiliki diagnosa ulkus diabetikum berusia dewasa (> 26 tahun), mendapatkan terapi antibiotik empiris, dan memiliki data rekam medis yang lengkap.

Pengumpulan data dilakukan
dengan menggunakan lembar
pengumpulan data meliputi nomor rekam medis, usia, jenis kelamin, tanggal masuk dan keluar dari rawat inap, diagnosa penyakit, antibiotik empiris yang diberikan serta data kultur dari laboratorium. Data yang diperoleh selanjutnya dianalisa secara deskriptif meliputi karakteristik pasien, pola pengobatan antibiotik empiris, pola resistensi dan sensitivitas bakteri terhadap antibiotik, dan kesesuaian pemilihan antibiotik empiris pada pasien ulkus diabetikum.

\section{HASIL DAN PEMBAHASAN}

Hasil penelitian yang diperoleh dari pengumpulan data rekam medik sebanyak 50 data pasien Ulkus diabetikum yang disajikan pada tabel 1-4.

Tabel 1. Karakteristik Pasien Ulkus Diabetikum

\begin{tabular}{|c|c|c|}
\hline Karakteristik Pasien & Jumlah & Persentase (\%) \\
\hline \multicolumn{3}{|l|}{ Jenis Kelamin } \\
\hline Laki-laki & 26 & 52 \\
\hline Perempuan & 24 & 48 \\
\hline Total & 50 & 100 \\
\hline \multicolumn{3}{|l|}{$\mathrm{Usia}^{[5]}$} \\
\hline 26- 35 tahun (dewasa awal) & - & - \\
\hline 36- 45 tahun (dewasa akhir) & 9 & 18 \\
\hline 46-55 tahun (lansia awal) & 20 & 40 \\
\hline 56-65 tahun (lansia akhir) & 17 & 34 \\
\hline$>65$ tahun (masa manula) & 4 & 8 \\
\hline Total & 50 & 100 \\
\hline \multicolumn{3}{|l|}{ Diagnosa penyakit } \\
\hline Ulkus Diabetikum (Wagner 1-2) & 12 & 24 \\
\hline Abses Diabetikum (Wagner 3) & 24 & 48 \\
\hline Gangren Diabetikum (Wagner 4-5) & 14 & 28 \\
\hline Total & 50 & 100 \\
\hline \multicolumn{3}{|l|}{ Riwayat penyakit } \\
\hline Diabetes Mellitus & 50 & 100 \\
\hline Total & 50 & 100 \\
\hline
\end{tabular}

Karakteristik jenis kelamin pada pasien ulkus diabetikum menunjukkan bahwa pasien ulkus diabetikum yang berjenis kelamin laki-laki adalah sebanyak 26 pasien dengan persentase sebesar $52 \%$, sedangkan pasien berjenis kelamin perempuan adalah sebanyak 24 pasien dengan persentase sebesar $48 \%$. Hal ini dapat disimpulkan bahwa jumlah pasien ulkus diabetikum di tahun 2017 yang terbanyak pada pasien berjenis kelamin laki-laki. Jenis kelamin laki-laki memiliki perbedaan yang signifikan terjadi neuropati perifer dan kerusakan pada bagian vaskuler yang merupakan faktor resiko terjadinya ulkus diabetikum $^{[16]}$. Jenis kelamin laki-laki memiliki resiko terjadinya ulkus diabetikum, karena laki-laki memiliki aktivitas di luar kegiatan, dibandingkan dengan perempuan ${ }^{[1]}$. Selain itu, pasien laki-laki dua kali beresiko mengalami neuropati yang menjadi faktor utama penyebab dari ulkus diabetikum, sehingga angka prevalensi dari ulkus diabetikum lebih banyak dialami oleh pasien laki-laki ${ }^{[11]}$. Namun, jenis kelamin tidak termasuk ke dalam faktor resiko ulkus diabetikum, melainkan faktor umur, lama menderita Diabetes Mellitus (DM), kebiasaan dan gaya hidup yang menjadi beberapa faktor resiko utama ulkus diabetikum ${ }^{[22]}$.

Karakteristik berdasarkan usia pada pasien ulkus diabetikum menunjukkan bahwa pasien ulkus 
diabetikum terbanyak adalah kelompok kategori pasien yang berusia 46-55 tahun (lansia awal) sebesar $40 \%$, diikuti oleh kelompok kategori pasien yang berusia 56-65 tahun (lansia akhir) sebesar 34\% Hal ini dikarenakan pada usia tersebut merupakan suatu waktu dimana seseorang akan mulai memasuki masa usia lanjut yang mengakibatkan adanya penurunan pada beberapa fungsi kerja tubuh. Ulkus diabetikum akan meningkat dan progresif pada usia diatas 50 tahun karena adanya penurunan pada beberapa fungsi fisiologis tubuh, seperti terjadinya penurunan sekresi insulin sehingga berakibat pada komplikasi jangka panjang, baik makrovaskuler maupun mikrovaskuler, salah satunya adalah ulkus diabetikum $^{[2]}$.

Karakteristik diagnosa penyakit pada pasien ulkus diabetikum menurut Wagner-Meggit, menunjukkan bahwa tingkatan ulkus diabetikum yang paling banyak adalah seluruh pasien ulkus diabetikum yang menjalani perawatan di RSUD Abdul Wahab Sjahranie pada tahun 2017 memiliki diagnosa Diabetes Mellitus. Dari 50 pasien diagnosa penyakit ulkus diabetikum yang paling banyak adalah $48 \%$ pasien yang memiliki diagnosa abses diabetikum (Wagner 3), $28 \%$ pasien mengalami diagnosa gangren diabetikum (Wagner 4-5) dan 24\% pasien menderita ulkus diabetikum (Wagner 12). Tingkat keparahan ulkus diabetikum dapat mempengaruhi distribusi bakteri, sesuai pernyataan tersebut, bakteri kokus gram positif (terutama staphylococci) umumnya menginfeksi ulkus diabetikum dengan tingkat keparahan yang ringan hingga sedang, sedangkan bakteri gram positif, gram negatif, dan serta bakteri obligat anaerob dapat ditemukan pada tingkat keparahan yang berat. Bakteri gram negatif (terutama Enterobacteriaceae) banyak ditemukan pada pasien ulkus diabetikum dengan kondisi kronis $^{[13]}$.

Pada jenis antibiotik, golongan antibiotik empiris yang paling sering digunakan adalah antibiotik golongan Sefalosporin, yaitu seftriakson sebanyak 43 obat dengan presentase sebesar $54,43 \%$, diikuti dengan obat golongan lain seperti Metronidazol sebanyak 28 obat dengan persentase sebesar 52\%. Seftriakson merupakan salah satu antibiotik golongan sefalosporin generasi ketiga yang umumnya aktif terhadap bakteri gram positif, tetapi kurang aktif dibandingkan dengan golongan sefalosporin generasi pertama. Waktu paruh obat ini mencapai 8 jam, jumlah seftriakson yang terikat pada protein plasma adalah sebesar 83-96\% [7]. Metronidazol merupakan antibiotik berspektrum luas yang memiliki aktivitas melawan bakteri positif dan bakteri gram negatif, sehingga obat ini digunakan sebagai antibiotik empiris sebelum dilakukan uji kultur bakteri untuk menentukan antibiotik definitif yang sesuai dengan bakteri yang terdapat pada ulkus diabetikum ${ }^{[18]}$. Selain itu, metronidazol merupakan obat antibiotik yang memilki mekanisme kerja obat yang aktif terhadap protozoa, sehingga hal ini menjadi pertimbangan dalam pemberian metronidazol sebagai terapi antibiotik empiris ${ }^{[9]}$.

Bentuk terapi antibiotik yang paling banyak digunakan adalah Seftriakson (36\%) sebagai terapi tunggal dan Seftriakson dan Metronidazol sebagai terapi kombinasi. Antibiotik kombinasi merupakan terapi pemberian antibiotik yang dilakukan lebih dari satu jenis antibiotik untuk mengatasi infeksi ${ }^{[10]}$. Pada kasus ulkus diabetikum, infeksi yang terjadi tidak termasuk infeksi yang ringan maka diperlukan pemberian kombinasi antibiotik, namun pada penggunaannya perlu diperhatikan dengan baik. Selain itu, tujuan dari pemberian antibiotik kombinasi yaitu dapat meningkatkan aktivitas antibiotik pada infeksi spesifik (efek sinergis), dan memperlambat serta mengurangi resiko timbulnya bakteri yang resisten. Kombinasi antara seftriakson dan 
metronidazol efektif diberikan sebagai terapi antibiotik empiris untuk infeksi pada tungkai bawah sehingga dapat memperluas spektrum aktivitas antibakteri melawan bakteri aerob, baik bakteri gram positif maupun gram negatif. Pemilihan terapi antibiotik pada ulkus diabetikum untuk derajat sedang sampai berat yaitu ampisilin sulbaktam atau sefalosporin generasi ketiga yang dikombinasi dengan metronidazol ${ }^{[6]}$. Penanganan pertama untuk infeksi ulkus diabetikum adalah menggunakan antibiotik yang memiliki mekanisme kerja spektrum luas dan anaerob untuk infeksi berat ${ }^{[19]}$.

Interval pemberian antibiotik empiris yang paling sering digunakan adalah $<7$ hari. Depkes RI menyatakan terapi antibiotik empiris spektrum luas diberikan dalam kurun waktu 2 sampai 3 hari. Durasi terapi diberikan antibiotik adalah selama 7 hingga 14 hari, meskipun beberapa infeksi memerlukan tambahan terapi selama 1 sampai 2 minggu $^{[4]}$. Sedangkan untuk rute pemberian obat secara keseluruhan $100 \%$ pasien diberikan terapi antibiotik empiris dengan jalur intravena (iv).

Tabel 2. Pola Pengobatan Antibiotik Empiris pada Pasien Ulkus Diabetikum

\begin{tabular}{|c|c|c|c|c|}
\hline No & \multicolumn{2}{|l|}{$\begin{array}{l}\text { Pola Pengobatan } \\
\end{array}$} & Jumlah pasien & Persentase (\%) \\
\hline \multirow[t]{11}{*}{1.} & \multicolumn{4}{|l|}{ Jenis Antibiotik } \\
\hline & \multicolumn{4}{|l|}{ Golongan Antibiotik } \\
\hline & Sefalosporin generasi II & Sefuroksim & 1 & 1,27 \\
\hline & \multirow[t]{4}{*}{ Sefalosporin generasi III } & Seftriakson & 43 & 54,43 \\
\hline & & Sefotaksim & 1 & 1,27 \\
\hline & & Sefaperazon & 2 & 2,53 \\
\hline & & Sefobaktam & 1 & 1,27 \\
\hline & Beta Laktam & Meropenem & 1 & 1,27 \\
\hline & Kuinolon & Siprofloksasin & 2 & 2.53 \\
\hline & Golongan Lain & Metronidazol & 28 & 35,44 \\
\hline & \multicolumn{2}{|l|}{ Total } & 79 & 100 \\
\hline 2. & \multicolumn{2}{|l|}{ Bentuk Terapi Antibiotik } & & \\
\hline \multirow[t]{5}{*}{ a. } & \multicolumn{2}{|l|}{ Antibiotik Tunggal } & & \\
\hline & \multicolumn{2}{|l|}{ Seftriakson } & 18 & 36 \\
\hline & \multicolumn{2}{|l|}{ Sefoperazon } & 1 & 2 \\
\hline & \multicolumn{2}{|l|}{ Cefobactam } & 1 & 2 \\
\hline & \multicolumn{2}{|l|}{ Siprofloksasin } & 1 & 2 \\
\hline \multirow[t]{7}{*}{ b. } & \multicolumn{2}{|l|}{ Antibiotik kombinasi } & & \\
\hline & \multicolumn{2}{|l|}{ Seftriakson + metronidazol } & 25 & 50 \\
\hline & \multicolumn{2}{|l|}{ Meropenem + metronidazol } & 1 & 2 \\
\hline & \multicolumn{2}{|l|}{ Sefotaksim + metronidazol } & 1 & 2 \\
\hline & \multicolumn{2}{|l|}{ Sefoperazon + siprofloksasin } & 1 & 2 \\
\hline & \multicolumn{2}{|l|}{ Sefuroksim + metronidazol } & 1 & 2 \\
\hline & \multicolumn{2}{|l|}{ Total } & 50 & 100 \\
\hline \multirow[t]{5}{*}{3.} & \multicolumn{2}{|l|}{ Waktu Pemberian } & & \\
\hline & \multicolumn{2}{|l|}{ Waktu pemberian <7 hari } & 30 & 60 \\
\hline & \multicolumn{2}{|l|}{ Waktu pemberian 7 hari } & 8 & 16 \\
\hline & \multicolumn{2}{|l|}{ Waktu pemberian 7-14 hari } & 12 & 24 \\
\hline & \multicolumn{2}{|l|}{ Total } & 50 & 100 \\
\hline \multirow[t]{3}{*}{4.} & \multicolumn{2}{|l|}{ Rute Pemberian } & & \\
\hline & \multirow{2}{*}{\multicolumn{2}{|c|}{ Intravena }} & & \\
\hline & & & 50 & 100 \\
\hline
\end{tabular}

Pada Tabel 3, menunjukkan pola resistensi bakteri terhadap antibiotik. Dari 50 data pasien ulkus diabetikum terdapat 16 bakteri yang menginfeksi pada pasien ulkus diabetikum yang terdiri dari 6 bakteri gram positif dengan persentase sebesar 50\% dan 10 bakteri gram negatif dengan persentase sebesar 50\%. Bakteri gram positif yang paling banyak menginfeksi pada pasien ulkus diabetikum adalah Enterococcus faecalis (20\%), Staphylococcus aureus (8\%), dan Streptococcus agalacticiae (8\%), sedangkan bakteri gram negatif yang 
paling banyak menginfeksi ulkus diabetikum adalah bakteri Klebsiella pneumonia (12\%), Proteus mirabilis (10\%), dan Acinobacter baumanii (8\%). Hal ini dikarenakan tiap rumah sakit yang berbeda, sehingga terjadi perubahan pola bakteri tiap waktu.

Pola resistensi terhadap antibiotik menunjukkan Enterococcus faecalis tidak menunjukkan kepekaan terhadap seftriakson, meropenem dan sefotaksim, namun memiliki sensitivitas sebesar 100\% terhadap Ampisillin-sulbactam dan Vankomisin serta $90 \%$ terhadap piperasilin-tazobactam. Staphylococcus aureus menunjukkan sensitivitas sebesar $100 \%$ terhadap semua antibiotik, sedangkan Streptococcus agalacticiae menunjukkan sensitivitas sebesar $100 \%$ terhadap Vankomisin dan $75 \%$ terhadap seftriakson, meropenem, sefotaksim dan ampisilin-sulbaktam. Klebsiella pneumonia menunjukkan $100 \%$ sensitif pada meropenem dan sensitif $50 \%$ pada seftriakson dan sefotaksim. Proteus mirabilis menunjukkan sensitif terhadap meropenem sebesar $60 \%$, serta Acinobacter baumanii menunjukkan sensitif $100 \%$ terhadap meropenem. Pada bakteri gram positif yang muncul sebagai bakteri resisten antibiotik dan perlu penanganan adalah bakteri MRSA (Methicillin Resisten Staphylococcus aureus) yang merupakan suatu infeksi bakteri yang perlu diperhatikan karena resistensi yang ditimbulkan galur MRSA. Pada penelitian ini diperoleh pasien positif terhadap MRSA, yaitu bakteri Staphylococcus aureus, bakteri MRSA mengalami resistensi yang disebabkan perubahan genetik yang disebabkan oleh paparan antibiotik yang tidak rasional, sehingga dapat terjadi transmisi bakteri yang dapat berpindah dari satu pasien ke pasien lainnya melalui alat medis yang tidak diperhatikan sterilitasnya, udara, meupun fasilitas ruangan, seperti selimut atau kain tempat tidur ${ }^{[15]}$. Dalam penelitian ini bakteri MRSA menunjukkan resisten terhadap semua antibiotik namun memiliki sensitivitas sebesar $66,67 \%$ terhadap Vankomisin. Galur Staphylococcus aureus yang resisten terhadap beberapa antibiotik, bahkan lebih resisten terhadap semua antibiotik yang beredar, kecuali terhadap vankomisin, galur Staphylococcus aureus yang resisten terhadap vankomisin masih jarang dilaporkan ${ }^{[20]}$.

Tabel 3. Pola Resisten dan Sensitivitas Bakteri terhadap Antibiotik

\begin{tabular}{llcc}
\hline \multicolumn{1}{c}{ Nama bakteri } & Bentuk & Jumlah & Persentase (\%) \\
\hline \multicolumn{1}{c}{ 1. Gram Negatif } & & & 2 \\
\hline Proteus vulgaris & Batang & 1 & 10 \\
Proteus mirabilis & Batang & 5 & 12 \\
Klebsiella pneumonia & Batang & 6 & 2 \\
Klebsiella pneumonia (ESBL) & Batang & 1 & 4 \\
Escherichia coli & Batang & 2 & 2 \\
Enterococcus cloacae & Kokus & 1 & 8 \\
Acinobacter baumanii & Batang kokus & 4 & 2 \\
Proteus penneri & Batang & 1 & 2 \\
Enterococcus faccium & Kokus & 1 & 4 \\
Morganella morganii & Batang & 2 & 2 \\
Serrata marcescens & Batang & 1 & 2 \\
Citrobacter freundii & Batang & 1 & 2 \\
Pseudomonas aerugynosa & Batang & 1 & 54 \\
Total (1) & & 27 & 8 \\
\hline 2. Gram positif & & & 20 \\
\hline Staphylococcus aureus & Kokus & 4 & 8 \\
Enterococcus faecalis & Kokus & 10 & 2 \\
Streptococcus agalacticiae & Kokus & 4 & 2 \\
Staphylococcus lugdonensis & Kokus & 1 & 6 \\
Staphylococcus haemolyticus & Kokus & 1 & 46 \\
MRSA & Kokus & 3 & 100 \\
Total (2) & & 23 & \\
\hline Total (1+2) & & 50 & \\
\hline
\end{tabular}


Tingkat sensitivitas dan resistensi bakteri terhadap antibiotik:

a. Bakteri gram negatif

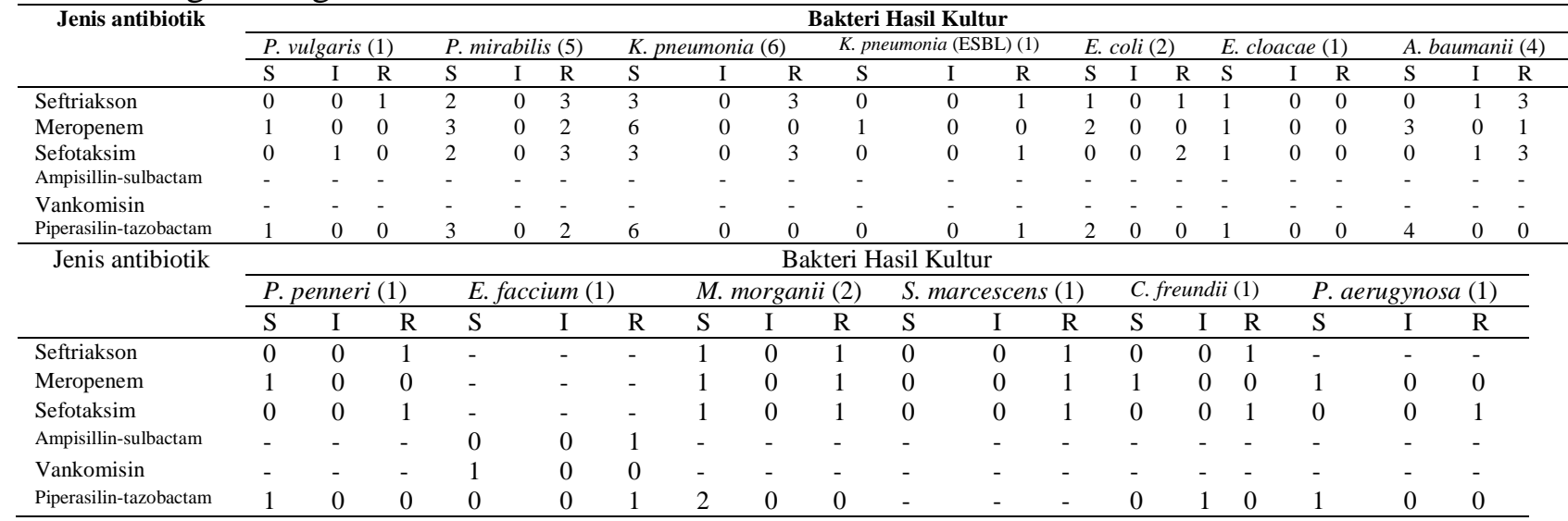

b. Bakteri gram positif

\begin{tabular}{|c|c|c|c|c|c|c|c|c|c|c|c|c|c|c|c|c|c|c|}
\hline \multirow[t]{3}{*}{ Jenis Antibiotik } & \multicolumn{18}{|c|}{ Bakteri Hasil Kultur } \\
\hline & \multicolumn{3}{|c|}{ S. aureus (4) } & \multicolumn{3}{|c|}{ E. faecalis (10) } & \multicolumn{3}{|c|}{ S. agalacticiae (4) } & \multicolumn{3}{|c|}{ S. lugdonensis (1) } & \multicolumn{3}{|c|}{ S. haemolyticus (1) } & \multicolumn{3}{|c|}{ MRSA (3) } \\
\hline & $\mathrm{S}$ & $\mathrm{I}$ & $\mathrm{R}$ & $\mathrm{S}$ & $\mathrm{I}$ & $\mathrm{R}$ & $\mathrm{S}$ & $\mathrm{I}$ & $\mathrm{R}$ & $\mathrm{S}$ & $\mathrm{I}$ & $\mathrm{R}$ & $\mathrm{S}$ & I & $\mathrm{R}$ & $\mathrm{S}$ & $\mathrm{I}$ & $\mathrm{R}$ \\
\hline Seftriakson & 4 & 0 & 0 & - & - & - & 3 & 0 & 1 & 1 & 0 & 0 & 0 & 0 & 1 & 0 & 0 & 3 \\
\hline Meropenem & 4 & 0 & 0 & - & - & - & 3 & 0 & 1 & 1 & 0 & 0 & 0 & 0 & 1 & 0 & 0 & 3 \\
\hline Sefotaksim & 4 & 0 & 0 & - & - & - & 3 & 0 & 1 & 1 & 0 & 0 & 0 & 0 & 1 & 0 & 0 & 3 \\
\hline Ampisillin-sulbactam & 4 & 0 & 0 & 10 & 0 & 0 & 3 & 0 & 1 & - & - & - & 0 & 0 & 1 & - & - & - \\
\hline Vankomisin & 4 & 0 & 0 & 10 & 0 & 0 & 4 & 0 & 0 & - & - & - & 0 & 0 & 1 & 2 & 0 & 1 \\
\hline Piperasilin-tazobactam & 4 & 0 & 0 & 9 & 0 & 1 & - & - & - & 1 & 0 & 0 & 0 & 0 & 1 & 0 & 0 & 3 \\
\hline
\end{tabular}

Keterangan: S: sensitifitas, I: intermediet, R: resistensi, 0: tidak ada, (-): tidak diujikan

Tabel 4. Kesesuaian Pemilihan Antibiotik Empiris

\begin{tabular}{|c|c|c|c|c|c|}
\hline \multirow{2}{*}{ No. } & \multirow{2}{*}{ Antibiotik Empiris } & \multirow{2}{*}{$\begin{array}{c}\text { Jumlah } \\
\text { Penggunaan (n) }\end{array}$} & \multicolumn{3}{|c|}{ Hasil Kultur } \\
\hline & & & Sensitivitas (\%) & Intermediate $(\%)$ & Resisten (\%) \\
\hline 1. & Seftriakson & 18 & $7(38,89)$ & $1(5,56)$ & $10(55,56)$ \\
\hline 2. & Sefoperazon & 1 & - & - & - \\
\hline 3. & Cefobactam & 1 & 0 & 0 & $1(100)$ \\
\hline 4. & Siprofloksasin & 1 & 0 & 0 & $1(100)$ \\
\hline 5 & Seftriakson + Metronidazol & 25 & $12(48)$ & $1(4)$ & $12(48)$ \\
\hline 6. & Meropenem + Metronidazol & 1 & $1(100)$ & 0 & 0 \\
\hline 7. & Sefotaksim + Metronidazol & 1 & 0 & 0 & $1(100)$ \\
\hline 8. & Sefuroksim + Metronidazol & 1 & - & - & - \\
\hline 9. & Sefoperazon + Siprofloksasin & 1 & 0 & 0 & $1(100)$ \\
\hline
\end{tabular}

Tabel 4 menunjukkan ketepatan antibiotik empiris yang dibuktikan dengan melihat hasil uji kultur setelah diberikan antibiotik empiris. Ketepatan pemilihan antibiotik empiris dengan hasil kultur untuk menilai ketepatan antibiotik sangat rendah. Pemberian antibiotik empiris hendaknya disesuaikan dengan bakteri yang ada pada masing-masing perawatan. Meningkatnya angka resistensi bakteri pemilihan antibiotik mempertimbangkan pada hasil kultur dan uji sensitivitas agar mendapatkan antibiotik yang dapat menargetkan bakteri patogen penyebab infeksi.
Apabila pasien memberikan respon klinis yang baik dengan memberikan antibiotik empiris maka pengobatan tersebut tetap dilanjutkan, namun jika pasien memiliki kondisi yang buruk maka pengobatan antibiotik tersebut harus menyeluruh untuk semua jenis bakteri yang terisolasi ${ }^{[14]}$. Kombinasi antibiotik dengan Metronidazol diperlukan apabila pada hasil kultur diperoleh bakteri anaerob. Metronidazol hanya memiliki aktivitas pada bakteri obligat anaerob. Dari pernyataan tersebut, kombinasi dengan metronidazol diperlukan apabila terdapat bakteri anaerob, sehingga pada 
penelitian ini penggunaan metronidazol sebagai terapi tidak sesuai karena dari hasil kultur tidak diperoleh adanya bakteri anaerob $^{[3]}$. Namun, Laboratorium Patologi Klinik bagian Mikrobiologi RSUD Abdul Wahab Sjahranie Samarinda tidak melakukan pengujian terhadap bakteri anaerob. Kultur bakteri anaerob lebih rumit membutuhkan teknik khusus selama pembiakan bakteri. Jika terjadi kontaminasi dengan udara selama pengiriman sampel ke laboratorium akan mengakibatkan bakteri tersebut tidak tumbuh selama pembiakan, sehingga untuk melakukan pengujian terhadap bakteri anaerob harus dilakukan oleh petugas mikrobiologi yang ahli di bidangnya. Oleh karena itu, pemilihan antibiotik untuk bakteri anaerob berdasarkan keparahan infeksi yang dikombinasi dengan antibiotik yang memiliki aktivitas pada bakteri aerob dan biasanya antibiotik empiris yang digunakan berlanjut untuk terapi definitif.

\section{KESIMPULAN}

Berdasarkan hasil penelitian yang telah dilakukan diperoleh kesimpulan, yaitu:

1. Karakteristik pasien ulkus diabetikum menunjukkan bahwa pasien ulkus diabetikum yang terbanyak adalah pasien berjenis kelamin laki-laki dengan persentase sebesar $52 \%$, dan perempuan sebesar 48\%, kategori umur 46-55 tahun sebesar $40 \%$, diagnose penyakit ulkus diabetikum dengan kategori diagnosa abses diabetikum (Wagner 3) sebesar $48 \%$.

2. Pola pengobatan antibiotik empiris pada pasien ulkus diabetikum menunjukkan bahwa pemberian antibiotik empiris yang sering diberikan di rumah sakit adalah antibiotik golongan sefalosporin generasi ketiga yaitu Seftriakson, bentuk terapi antibiotik empiris terbanyak adalah pemberian antibiotik seftriakson sebagai terapi tunggal dan antibiotik seftriakson dan
Metronidazol sebagai terapi kombinasi.

3. Pola resisten dan resistensi bakteri terhadap antibiotik menunjukkan bahwa berdasarkan bakteri penginfeksi antibiotik yang masih sensitif adalah meropenem dan antibiotik yang mulai resisten adalah seftriakson dan sefotaksim.

4. Ketepatan pemilihan antibiotik empiris dapat menunjukkan bahwa seftriakson persentase sensitif (38,89\%), intermediate $(5,56 \%)$ dan resisten $(55,56 \%)$, sedangkan seftriakson+ metronidazol persentase sensitif $(48 \%)$, intermediate (4\%) dan resisten $(48 \%)$.

\section{UCAPAN TERIMA KASIH}

Penulis mengucapkan terimakasih kepada pihak RSUD Abdul Wahab Sjahranie Samarinda.

\section{DAFTAR PUSTAKA}

[1] Ahmed A. A., Algamdi S. A. Algurashi A., Alzahrani A. M., and Khalid K. A., 2014, Risk Factors for Diabetes Foot Ulceration. Among Patients Attending Primary Health Care Services, The Journal of Diabetic Foot Complications, 6 (2), 40-47.

[2] Akbar T. G, Karimi Jazil, Anggraini Dewi, 2014. Pola Bakteri dan Resistensi Antibiotik pada Ulkus Diabetik Grade Dua di RSUD Arifin Achmad Periode 2012. JOM, Vol. 1 No. 2

[3] Brook I., Wexler H.M. and Goldstein E.J.C., 2013, Antianaerobic Antimicrobials: Spectrum and Susceptibility Testing, American Society for Microbiology, 26 (3), pp.523-539.

[4] Dipiro, JT., 2009. Pharmacotherapy Handbook $7^{\text {th }}$ edition, Mc-Graw Hill, New York

[5] Depkes RI, 2009. Klasifikasi Umur Menurut Kategori. Jakarta: Ditjen Yankes. 
[6] Frykberg, R.G., Zgonis, T. Armstrong, D. G., et al, 2006. Diabetic Foot Disorders: AD. G., et al., 2006. Diabetic Foot Disorders: $A$ Clinical Practice Guideline.

[7] Gunawan, Sulistia, 2016. Farmakologi dan Terapi. Jakarta: Fakultas Kedokteran Universitas Indonesia.

[8] Harmita dan Radji, M., 2008. Kepekaan Terhadap Antibiotik. Dalam: Buku Ajar Analisis Hayati, Ed.3. EGC, Jakarta: 1-5

[9] Katzung, B., Susan, B. Masters., \& Anthony, J. 2010. Basic and Clinical Pharmacology 10 th Ed. Mc-Graw Hill Companies, USA.

[10] Kementerian Kesehatan RI, 2011. Peraturan Menteri Kesehatan Republik Indonesia: Pedoman Umum Penggunaan Antibiotik.

[11] Khalique, S., 2014. Evaluation of the Effect of Inadaptable Risk Factors and Social status on Diabetic Foot. International Journal of Endorsing Health Science Research, 2 (2), pp. 78-81.

[12]Leese, G., Nathwani, D. \& Matthew Young, 2009. Use of Antibiotics in People with Diabetic Foot Disease: A Consensus Statement. The Diabetic Foot Journal. 12(2), pp. 10

[13]Lipsky B.A., 2004. Medical Treatment of Diabetic Foot Infections. Clinical Infection Disease, 39, 104-14.

[14]Lipsky B.A., Berendt A. R., Comia P.B., Pile J.C., Peters E.J.G. and Armstrong D.G., 2012, 2012 Infectious Disease Society of America Clinical Practice Guideline for The Diagnosis and Treatment of Diabetic Foot Infections, Infectious Disease Society of America Guideline, 132-173.

[15] Mahmudah, R, Soleha, TU dan Ekowati, C. 2013. Identifikasi
Methicillin- Resistant Staphylococcus aureus (MRSA) pada Tenaga Mesdia dan Paramedis di Ruang Intensive Care Unit (ICU) dan ruang Perawatan Bedah Rumah Sakit Umum Daerah Abdul Moeloek. Medical Journal of Lampung University, Vol.2 pp. 71-76

[16] Maskari A. F., Sadig M., 2007. Prevalence of Risk Factor for Diabetic Complications, Biomed Central Family Practice, 8, 59-67.

[17] Ninisita, Sri Hadi, Djoko Wahyono, I Dewa Putu Pramantara S., 2012. Evaluasi Penggunaan Antibiotika pada Infeksi Kaki Diabetik: Studi Kasus Rawat Jalan di Poliklinik Endokrinologi RSUP Dr. Sardjito Yogyakarta. Jurnal Managemen dan Pelayanan Farmasi Vol 2 No 4.

[18] National Institute for Health and Care Excellent, 2015. Diabetic Foot Problem Prevention and Management, National Institute for Health and Care Excellence, 19.

[19]Noor, S., Rizwan, U. K. \& Jamal, A. 2017. Understanding Diabetic Foot infection and Its Management Diabetes \& Metabolic Sindrome. Clinical Research \& Reviews, 11(2); 149-156.

[20]Radji M., Siti F., Nurgani, A., 2011. Antibiotic Sensitivity Pattern of Bacterial Pathogens in The Intensive Care Unit of Fatmawati Hospital Jakarta. Asian Pac J Trop Biomed, Jakarta 1,1, pp. 39-42.

[21] Waspadji, S. Kaki Diabetes. Dalam: Sudoyo AW, Setyohadi B, Alwi I, Simadibrata M, Setiati S, editor, 2006. Buku Ajar Ilmu Penyakit Dalam Jilid III. Edisi ke-4. Jakarta: Interna Publishing.

[22]Wells,. B., Dipiro, J., \& Terry, L. 2009. Pharmacotherapy Handbook, Seventh Edition, The McGraw-Hill Companies, Inc. New York 